\title{
Hindu City and Just Empire: Banaras and India in Ali Ibrahim Khan's legal imagination
}

\author{
Nandini Chatterjee \\ University of Exeter
}

\begin{abstract}
This article examines the career and ideas of a late Mughal administrator, a Shi'a Muslim called Ali Ibrahim Khan, who was appointed magistrate of the north Indian city of Banaras after its conquest by the East India Company in 1781, and remained in that position until his death in 1792. Engaging with recent research on legal pluralism on the one hand, and on legal and cultural intermediaries on the other, this paper examines the imagination of imperial, religious and legal spaces by this prolific historian, poet and legal ethnographer, an under-studied protagonist of the process of transition to colonialism in India. Using a range of Persian-language manuscript sources in addition to archival and published material in Urdu and English, the article reveals the principles of Ali Ibrahim Khan's pragmatic but principled efforts to reconcile recognisably Islamic legal principles and procedures with the demands of the emerging colonial situation, and his systematic reference to locality and custom in order to do so.
\end{abstract}


Reluctantly presiding over a trial in Banaras in 1781, Ali Ibrahim Khan, the Britishappointed magistrate of that recently conquered city, observed the procedures of a "trial by ordeal among the Hindus." Ali Ibrahim Khan's detailed observations, which we can deem one of the earliest works of legal ethnography produced by an Indian, were accompanied by a typology of such ordeals, apparently gleaned from the Brahmin pandits attached to his court, and an appendix containing relevant extracts from a dharmasastric text, the Yajñavalka Smriti. The result was an article in the first issue of the Asiatick Review, that epitome of scholarly and official Orientalism in India. ${ }^{1}$

We might well have taken the events at Ali Ibrahim Khan's court, and the resulting journal article, to be symptomatic of a distinctively colonial and modern method of dealing with cultural, religious and legal diversity, in which Indian society was taken to be composed of distinct and mutually exclusive religious collectives, each possessing a complete set of laws which had to inevitably apply to all its members but no others. ${ }^{2}$ We may also have taken this Muslim judge's account as especially convincing evidence of the vitality and persistence of Brahminical knowledge and legal traditions, and indeed, of their formal incorporation within the legal structures of precolonial India. ${ }^{3}$

However, this paper comes to a somewhat different conclusion, by considering not only the legal practices reported, but also the opinions expressed by the key protagonist - the judge himself. Ali Ibrahim Khan noted that he had allowed the ordeal to be undertaken only after failing to convince the parties and his own advisory pandits (Brahmin scholar-experts) that such procedures, while appropriate in the realms of Hindu kings, were unsuitable within the territories of the Company. While clearly curious about the eventual proceedings, and surprised by the outcome (whereby a man held a red-hot iron ball in his hand without being burnt, thus proving his innocence), Ali Ibrahim Khan remained unconvinced about the value of the practice for ascertaining the facts for a legal case. He remanded the "appellor" (accuser in eighteenth-century English criminal law) to custody for a week, as a deterrent against further such demands for trial by ordeal, and continued to believe that "if such a trial could be seen once or twice by several intelligent men, acquainted 
with natural philosophy, they might be able to assign the true reason, why a man's hand may be burnt in some cases, and not in others."4

Ali Ibrahim Khan's critical knowledge of Islamic and "Hindu" legal traditions, his reflections on their mutual relationship, and his repeated references to locality and sovereignty as determining legal principles, opens an unused window into the recently rejuvenated field of legal pluralism. Legal pluralism, that is, separate laws for different parts of the population residing within the same overarching political and legal system, was a quintessentially imperial phenomenon. Older studies of the phenomenon addressed the formal legal pluralism of French, Dutch and British empires - all of which officially recognised parts of various indigenous laws for the benefit of different groups of colonial subjects. ${ }^{5}$ Since the 1960 s, on the other hand, the concept was also deployed to examine the hiatus between formal or state law and other effective moral codes, especially those that "plebeian" society lived by. ${ }^{6}$

The most recent literature on imperial history and legal pluralism, exemplified by the ambitious work of Lauren Benton, has moved our understanding beyond both formal legal pluralism with "neatly stacked" legal systems, as well as a binary opposition between state and non-state law. Instead, Benton has offered a vision of uneven legal geographies, replete with maritime corridors, treacherous waterways, sudden fissures and inaccessible highlands across which litigants adroitly "jockeyed" for maximum gains. ${ }^{7}$ This literature encourages us to think about "jurisdiction" as a legally structured, but also fractured and contested space, on which rested the precarious but violent reality of empires.

Benton's conception also allows us to investigate the perceptions and actions of those petty legal authorities, the indigenous law officials - the limits of whose agency may be open to debate, but whose experiences, practices and beliefs certainly provided the everyday texture of imperial law. While close attention to European legal thought has enriched the intellectual history of empire, or at least the European conceptions of it, ${ }^{8}$ and rich studies of colonial litigants have revealed both clashes of expectations and scope of subaltern agency, little is known about the "jurispractice,"9 or situational rationales of indigenous legal officials - who in their own persons and actions straddled the boundary between state and society. Recognising that these 
"little men" were also thinkers, and that they drew on rich cultural and intellectual resources in their conceptions of empire, allows us to build upon and transcend the social history of colonial manpower. ${ }^{10}$ Quite like certain Berber notables, whose personal and intellectual negotiation of the fraught Catholic-Islamic world of the sixteenth-century Mediterranean has received significant attention, ${ }^{11}$ late Mughal/early colonial judges and administrators have much to tell us about how empire was not only perceived and experienced but actuated in India in the late eighteenth century. ${ }^{12}$

Studying the very court that Ali Ibrahim Khan presided over, Radhika Singha argued for the Weberian role of colonial law, buttressing the colonial state's exclusive claim to legitimate violence. In her richly textured study, she also demonstrated how that claim was eventually compromised, both in deference to Indian sensibilities and in the interest of order. ${ }^{13}$ Assuming a more dialogic model (but in a different way from Singha), Robert Travers has shown how British justifications as well as critiques of the East India Company's empire in India in the eighteenth century shoehorned what had been learnt about Indian laws and political principles into the English political theory of "ancient" and inviolable "constitutions," which alone gave legitimacy to political power. ${ }^{14}$ In continuing to pay attention to the process of intellectual and social layering of imperial regimes, this article turns from British jurists and Residents to a thoughtful as well as powerful Indian protagonist. Fortunately for us, and unusually for a man "between worlds," Ali Ibrahim Khan, being a prolific poet, literary critic, historian, avid letter-writer and aspiring jurist, has left us copious records of his thoughts and experiences, from which we can deduce not just angst and the urge to negotiate moral, legal and political borders, but his methods and principles for doing so.

Deducing those principles draws us ineluctably into the usually distinct field of Islamic law in South Asia. Scholarship produced since the 1980s has hugely enhanced understanding of Islamic law as an evolving jurisprudential tradition, ${ }^{15}$ continuously developed by specialist scholars, fuqaha, who, as part of the larger body of learned, or 'ulama, have proved perfectly capable of adapting to altered social and institutional circumstances. ${ }^{16}$ While scholars of Islam in South Asia have repeatedly pointed to the diversity, in general, of "Islam in practice," 17 the many sources of 
"Islamic" codes of thought and practice, ${ }^{18}$ and the constant "ambiguity" in adherence to shari ' $a$ (or deviation from it), ${ }^{19}$ it is now time to return attention to the practice of Islamic law in India, before its jurisdiction was truncated by colonial rule, and before it became a species of family law and a marker of community identity. ${ }^{20}$ With insights derived from studies in the "high" Mughal period, ${ }^{21}$ we can begin to understand how a Shi`a Muslim poet-jurist-administrator might negotiate the emergent political terrain of nested empires in late eighteenth-century Bengal and Banaras.

\section{Setting the Scene: The man and his context}

Ali Ibrahim Khan was born around 1730 in an old and highly regarded Shi'a family of Azimabad (Patna). ${ }^{22}$ Nephew of a jurist and judge and grandson of a scholar, ${ }^{23}$ he turned out to be an administrator, diplomat, legal commentator, judge, poet and literary critic — of Persian and Rekhta (proto-Urdu) poetry. ${ }^{24}$ Ali Ibrahim Khan figures several times in the eighteenth-century Persian-language histories, especially with regard to his life and career prior to his appointment in Banaras. This was no doubt because he was very well known to the administrator-historians who authored these works, and was even married to the daughter of one of them. ${ }^{25}$

Ali Ibrahim Khan's career stretched across a number of the eighteenth-century states that rose in north India in the wake of the emasculation of the Mughals, and he was personally known to the royal families of Bengal, Awadh, the Maratha confederacy and the Mughals themselves. ${ }^{26}$ When ten years old, he was taken from Patna to Murshidabad in 1740 together with other skilled administrators by Nawab Ali Vardi Khan, ${ }^{27}$ the Persian deputy-governor of Bihar who usurped the Nawabi of Bengal. ${ }^{28}$ He witnessed the revolution of 1757, which turned the East India Company into king-makers in Bengal. He then worked in important administrative positions under Nawab Mir Qasim, negotiated on behalf of the latter with the British and the Nawab of Awadh, weathering the battlefields of Buxar in 1765. Next, he moved on to working under another Shi'a bureaucrat, Muhammad Reza Khan, naib-nazim in the dual system of Indian-run and British-managed government in Bengal after the grant of Diwani, ${ }^{29}$ and rendered Reza Khan invaluable assistance when the latter was accused of corruption in a politically-motivated trial spearheaded by Warren 
Hastings,${ }^{30}$ before eventually falling out with him over the patronage of a particular dancing girl. ${ }^{31}$

Hastings, who had been sent to Bengal in order to abolish the dual system of government, and assert unqualified Company authority, proved to be the most durable patron for Ali Ibrahim Khan, and Khan received his biggest career break in connection with one of Hastings' most controversial operations - the takeover of the Banaras zamindari in 1781. Banaras was a "little kingdom"- a zamindari risen from a family of Bhumihar Brahmin revenue farmers subordinate to the Nawabs of Awadh - the latter themselves shaking off centralised Mughal control from the 1720s. These tax-collecting henchmen turned rebellious upstarts, ${ }^{32}$ fended off attacks by other local warlords, attacked or ignored Oudh officials, wooed the tottering Mughals and the ambitious Marathas, and with the support of the East India Company wrested increasingly greater recognition of autonomy from Awadh, in 1752, 1757, 1764 and $1765 .^{33}$ The initial strategy of the Company was to extract tribute rather than to govern directly. It was only when a Banaras raja, Chait Singh, refused to produce an additional "extraordinary" annual contribution of five hundred thousand rupees and a regiment of two thousand horsemen to subsidise Anglo-French wars that the question of British sovereignty over this territory became an important matter, to be tested through force of arms.

In the ensuing confrontation in 1781, Chait Singh was routed. Banaras came under British control and Ali Ibrahim Khan found himself a job as the magistrate of the city. It was in that capacity, negotiating the theoretical and asserted claims of many past and present rulers - the British, the Rajas of Banaras, the Nawab of Awadh, and the turbulent Maratha chiefs - that he penned his historical, legal and literary works, in all cases attempting to reconcile territorially expansive and vigorously debated claims of authority and expertise to local tastes and necessities. In understanding the work and vision of Ali Ibrahim Khan, judge-magistrate, ethnographer, poet, literary critic and historian, it is essential to consider all the genres of writings through which he imagined space, and justice in it.

\section{Being the Observer: Judge in a city of "many religions"}


After 1781, the Rajas of Banaras lost many of their "royal" prerogatives-including the right to maintain order, to dispense justice and to control the mint, ${ }^{34}$ several of these functions being amalgamated in the newly created post of Chief Magistrate in Banaras - to which Hastings appointed Ali Ibrahim Khan. Hastings noted the particular challenges of dispensing justice in Banaras-buzzing with temples, pilgrims, trade and rich pensioners, and a significant place for both Hindus and Muslims. Hastings deemed Khan just the man for such a job, with his "moderation, disinterestedness, and good sense," that is, his lack of bigotry as well as ambition. In order to meet his challenges, Khan was provided with a handsome salary of 2,500 rupees a month, and set atop the Kotwali (police station), the criminal or Faujdari Adalat and the civil or Diwani Adalat. The two latter, presided over by daroghas, were provided with legal experts—maulavis and pandits—but the final appeal lay with Ali Ibrahim Khan. ${ }^{35}$

It was in this context that Khan produced the extraordinary document discussed at the beginning of this article - a critical ethnography of the practice of ordeals under Hindu law. ${ }^{36}$ A very significant portion Ali Ibrahim Khan's criticisms can be called "jurisdictional"- he reported having tried long and hard (over four months, in fact) to convince his own court pandits and the parties that such a mode of securing evidence was "not conformable to the practice of the Company's government," and having suggested a non-sanguinary oath instead-"by the waters of the Ganges or the leaves of the tulasi in a little vessel of brass, or by the book Herivansa [sic., Harivamsa], or the stone Salgram, or by the hallowed ponds... all which oaths are used at Benares." 37 In the end, in the face of obstinate insistence, he reported having given in, on the basis that the parties were Hindus, the procedure was explicitly sanctioned by the dharmasastras, that it was utilised in the territories of [other] Hindu rajas and, charmingly, because he was curious about the outcome. Khan found himself amazed by the accused emerging unscathed, but refused to relinquish his scepticism-continuing to believe that this was a trick with a natural explanation.

Wherein arose Ali Ibrahim Khan's scepticism and disapproval? We can compare his comments to those of his erstwhile patron, Muhammad Reza Khan. Ten years ago, in 1772, Reza Khan, then battling the growing encroachment on his authority by 
the Company Government headquartered at Calcutta, had vehemently rejected Hastings' proposal of separate laws for Hindus and Muslims, or of associating Brahmin judges with a proper (that is, Islamic) court. While revealing similar rich knowledge regarding the contents and regional specificities of "Hindu laws," and suggesting that people could choose alternative arbitration forums if they so preferred, Reza Khan had insisted that

the Gentoos are subject to the true faith and to order a magistrate of the faith to decide in conjunction with a Brahmin would be repugnant to the rules of the faith - and in a country under the dominion of a Mussulman emperor it is improper, that any order should be issued inconsistent with the rules of his Faith, or that innovations should be introduced in the administration of justice. ${ }^{38}$

Times had moved on since Reza Khan's fruitless protest, and Ali Ibrahim Khan was well aware of the expectations of his employers. Indeed, he was astute enough to assert his jurisdictional claim (that such procedures were alien to his court) not on the basis of Islam, but on the basis of colonial authority. Indeed, in the turbulent city of Banaras, frequented by many would-be empire-builders, the jurisdiction of his court and the sanctity of his preferred court procedures had to be based on the Company's authority and its alleged norms of legal procedure. When formidable Maratha sardars and their henchmen took it upon themselves to imprison their debtors, and occasionally kill them while in "custody," Ali Ibrahim Khan's best bet, following frustrating requests to bring the dispute to his court, was to rely on the British Resident to lean on the Maratha general, who in turn, predictably asserted his own royal claims and equivalence ("friendship") with the British. ${ }^{39}$ The pandits, on the other hand, were the Company's servants, just like himself-and it is notable that Ali Ibrahim Khan here deployed the jurisdictional argument to support his own interpretation of what the Company's legal norms required of court procedure.

His capitulation, albeit after a considerable period of reflection (and no doubt, effort to pressurise his opponents), as well as the reasons proffered for this change of heart, suggest a new sensibility of legal pluralism - one that recognised "Hindu law" as a separate entity, formally and inevitably applicable to certain kinds of legal 
subjects (Hindus), given certain textual prescriptions (in the dharmasastras). Certainly, the textual emphasis was completely new-for although there existed by that time an eight-hundred-year-old tradition of Muslim commentary on Hindu religious practices, including commentaries on Hindu salvific doctrines and biospiritual exercises (especially yoga), ${ }^{40}$ and monumental translations of epics and ethical-philosophical texts sponsored by the Mughals, ${ }^{41}$ there does not appear to have been a single Persian translation of the dharmasastras or their commentaries until the Code of Gentoo Laws began to be prepared under British patronage. What is particularly striking is that Ali Ibrahim Khan felt it necessary to name not just his advisors, but quote from the texts they cited-appending the relevant section from the Yajñavalka Smriti, "verbally translated," perhaps by the same authorities. As such, he can be seen as an active participant in the much-studied process of colonial textualisation of Indian legal traditions. ${ }^{42}$

Nevertheless, he retained other principles that allowed him to critically transcend such legal sectarianism. These were the principles of "natural philosophy," and the nature of realms. While I have not been able to trace the exact intellectual lineage of Mulla Nasir, Ali Ibrahim Khan's maternal grandfather, nor identify with confidence the Shirazi scholar with whom Mulla Nasir reportedly travelled to Shiraz for his studies, the likelihood of his having been influenced by emigrant Shi'a Usuli (or rationalist, interpretive, clerical authority-oriented) 'ulama is very high. In the early eighteenth century, many such Usuli families, losing the dominance they had enjoyed in Safavid Iran, moved to India, first to Bengal and then to Awadh. ${ }^{43}$ Eventually, such scholars would come to impose a rationalist and clericalist orientation on the Awadh state in the early nineteenth century. ${ }^{44}$ But if not specifically Shi'a, a rationalist-empiricist approach aimed at training experts in adjudication and administration was already manifest in the hugely popular curriculum called Dars-i Nizamiyya which was taught at and disseminated by the Firangi Mahall madrassa at Lucknow, endowed by the Mughal emperors. ${ }^{45}$ Moreover, Banaras was the adopted home of Shaikh Muhammad Ali "Hazin" Gilani, the irascible Usuli jurist, poet and literary critic. We have evidence that Ali Ibrahim Khan appreciated and endorsed Hazin's poetic opinions, whatever he may have thought of his jurisprudence. ${ }^{46}$ 
As Ali Ibrahim Khan said, Hindu ordeals, with impeccable scriptural standing but of dubious rationality, may be acceptable in the realms of Hindu kings - and we shall discuss later whom he meant-but not in the Company's lands. His recommendation of oaths instead of ordeals is interesting for two reasons. While superficially the oaths recommended sound similar to the multireligious pledges essayed in the English Mayor's Courts from the mid-eighteenth century, ${ }^{47}$ Ali Ibrahim Khan's preference for them was conditional. In a case such as this (alleged theft), oaths were acceptable, undoubtedly because they were a valid form of evidence under Islamic law. ${ }^{48}$ On the other hand, Ali Ibrahim Khan would later vociferously oppose the administration of similar oaths to court officials - an opposition Radhika Singha incisively showed to be linked to questions of status and public standing. ${ }^{49}$ Thus, while unacceptable as humiliating public trials of probity for important officials, oaths could be satisfactorily administered to under-trials, be usefully distinguishable by religion (thus catering to British sensibilities), and leave both Ali Ibrahim Khan's scepticism and Islamic legal procedure unscathed.

Thus in referring to local custom (over religious scriptures), Ali Ibrahim Khan may have been attempting to avoid ideological confrontation with his employers, the British (and their vision of multiple religion-based legal traditions), while also maintaining recognisable Islamic legal procedure, by, not despite, reference to local custom. Brahmanical scriptural-legal texts, on the other hand, remained suspect, and susceptible to his rationalist criticism, possibly from an Usuli intellectual position that foregrounded rationality, and the right of juristic interpretation by appropriately trained experts.

\section{Custom as Justice: Ali Ibrahim Khan on commercial law}

Despite this strategy of rationalist detachment, and his unquestionable diplomatic skills, as Hastings' power and patronage receded, Ali Ibrahim Khan found himself pushed into taking more oppositional positions with other British superiors, jealous of his position in the city and court. Quite plausibly, Francis Fowke, the then British Resident, saw in him an instrument of Warren Hastings' open hostility. ${ }^{50}$ A subsequent Resident, Jonathan Duncan, well known to South Asianists through the works of Cohn and Singha, proved to be a greater challenge. During their barely concealed conflicts, Ali Ibrahim Khan was moved to articulate more autonomous 
lines of legal interpretation, in which the validity local custom, once again, proved to be his most valuable principle.

Appointed in 1787, Duncan proceeded to produce a voluminous survey of the revenues, government and legal structure of Banaras, together with recommendations for important changes in policy, many resulting in a constraining of Ali Ibrahim Khan's power. In general, despite Ali Ibrahim Khan's efforts, Duncan still found the legal structures of the region rickety and barely functional. ${ }^{51}$ Duncan noted qazis who had been without regular arrangements for payment for several years, and the complete absence of any revenue courts (revenue had been left under the raja's jurisdiction). There was said to be a functioning mulki (country/royal) adalat under the Banaras raja's jurisdiction (and manned by a qazi) which mainly dealt with inheritance cases.

As for Ali Ibrahim Khan himself, Duncan noted that while Khan was a good man and a good judge, he tended towards softness and procedural laxity, even if such flexibility was in keeping with local cultural expectations. As part of his package of legal reform, Duncan suggested making Ali Ibrahim Khan's court subordinate to that of his own (as the Resident). He explained that making Khan's decisions "subject to an appeal would obviate his [Khan's] reliance so much on untrustworthy judges of civil and criminal courts who were taking undue advantage of his liberality because the idea of an appeal would make Ali Ibrahim Khan pay stricter attention to the proceedings of the courts under him." 52

Earlier in the year in which he produced his report (1788), Duncan had toured the zamindari in the company of the raja, and instituted three new town courts, at Ghazipur (Maulvi Amirullah), Jaunpur (Mufti Karimullah) and Mirzapur (Lala Bakshi Singh) - the last appointment apparently aimed at pleasing the important Hindu commercial groups of that city. ${ }^{53}$ In each of these judicial establishments, the judges were directed to apply Hindu law to Hindus and Islamic law to Muslims, as far as civil causes were concerned (in direct reference to regulations adopted in Bengal in 1772), and were each provided with a full establishment, including a maulvi and two pandits as assessors. In spite of this provision for expert advice, the judges expressed some bewilderment about the requirements of their position and role. For example, 
soon after their appointments, all these judges wrote to Jonathan Duncan, seeking clarifications - about their jurisdiction, their relationship with existing qazis and muftis, and the applicable laws and procedure. ${ }^{54}$ Unsurprisingly for an important commercial centre, several of these questions were about financial instruments. Bakshi Singh of Mirzapur asked whether there were time limitations for claiming back mortgaged property, ${ }^{55}$ and Muhammad Nasir ud-din, judge of the Mulki Diwani Adalat (an older judge not appointed by Duncan) asked the same question with regard to debt recovery. ${ }^{56}$

The issues of mortgage and limitations were complex enough for Duncan to refer them to Ali Ibrahim Khan for his expert comments. Ali Ibrahim Khan proceeded to explain what, "according both to the Mohammedan and Hindoo law [were] the nature, rates and practice of mortgages as observed in the City of Banaras and throughout the Zemindary appertaining to it." Translating the term mortgage as "rahen" [sic] in Mohammedan law, and "bandhak" in Hindu law, he once again acknowledged colonial assumptions regarding mutually exclusive legal systems, marked by religion, categories and language. However, this gesture was then transcended by his categorisation of the commercial device by the conditions attached to it-which appeared identical in the two allegedly distinct legal systems. He noted that there were "rahens" with and without time limitations attached, and that while time-limited "rahens" could lead to sale of the mortgaged property in case of default, there were differences of opinions among the "ulama regarding such forced sales (bai" al-wafa) of 'pledged' property. Similarly, he offered "girow" [sic; girwi] and "bandhak" as corresponding legal terms from within Hindu law, once again pointing out that these varied according to whether or not a profit was derived from them (for instance through use of the property mortgaged) and whether or not it was timelimited.

Noting that Warren Hastings had himself sought his (Ali Ibrahim Khan's) opinion regarding the time-limitation of causes related to mortgages, Khan reiterated his earlier advice against the blanket adoption of an effective statute of limitations. He argued that a rigid doctrine of time-limitation would consist of injustice, given the variety of commercial transactions encompassed by the blanket term "mortgage" and the range of time-related provisions in the existing laws, both Hindu and Islamic, 
which people in Banaras were familiar with. He also felt that a rigid doctrine of timelimitation would strengthen the hands of the wealthy, powerful and unscrupulous. For example, the mortgagee may have discouraged payment in order to keep using the property, and the mortgager, especially if poor, may not have been able to raise the repayable amount in twelve years (the envisaged period of limitation). Similarly, unscrupulous usurpers of property could forge mortgage deeds and claim long-term possession; without judicial investigation, such usurped property could never be retrieved. ${ }^{57}$

In this response, Ali Ibrahim Khan revealed a sensitive understanding of a variety of commercial devices, as well as the situational uses and abuses of legal provisions in a vibrant commercial centre of eighteenth-century northern India. We have extensive evidence of the widespread use of rahn, by both Hindus and Muslims, these transactions being recorded under the seal of the qazi in ubiquitous rahn-namas from all major commercial centres of northern, western and central India, at least from the seventeenth century. ${ }^{58}$ Khan chose to represent the device as deriving from distinct legal traditions, Hindu and Muslim, not only distinguished by language (rahn and bandhak) but also in terms of textual sources. As far as Islamic law was concerned, he referred accurately to debates among Indian 'ulama over loopholes that permitted usury. ${ }^{59}$ Suppressing this contentious debate over Islamic prohibition of usury, Ali Ibrahim Khan simply noted that rahns were mortgages, that in some cases could be transformed into effective sales called bai ' al-wafa. Thus Khan invested his energy in retaining the customary safeguards against misuse of this undoubtedly popular device, rather than risk fruitless jurisprudential debate over the merits of usury with a trading company. In doing so, he referred to the local realities of commercial practice, and posed the legitimacy of established customs of the region against a codifying approach that would impose a rigid time-limit on claims that required greater flexibility in order to be socially equitable. Although acknowledging the categories of "Hindu" and "Muslim" and indeed, the distinct body of jurisprudence that related to Islam, the legal traditions he sought to defend in this instance derived from locality and familiarity (being customary), rather than any abstract community defined by law.

\section{Being the Mufti: Situational legal interpretation and judicial practice}


On another occasion in the same year (1788), Khan was called upon to comment upon the far more contentious matter of mutilations as punishment in Islamic criminal law. ${ }^{60}$ This was a case of robbery, which had been adjudicated by the more severe Nasir ud-din at the Mulki Adalat. Two lower-caste men had snatched a nose-ring from a Marwari woman performing the panchkosi pilgrimage through the city in the company of her family. The miscreants had been caught by the woman's brother, who also turned them over to the Mulki Adalat. Both men were known criminals, convicted on several previous occasions despite having signed bonds of good behaviour. Nasir ud-din sentenced them to amputation of a hand and the diagonally opposite foot on the basis that such was the non-negotiable (hadd) punishment for highway robbery. ${ }^{61}$ The Resident, obviously unhappy with the judgment, consulted Ali Ibrahim Khan, who adroitly avoided questioning the legal provision itself, and questioned instead the construction of facts. Disputing that robbery in broad daylight, within the precincts of the city, could be construed as highway robbery, he recommended understanding the act as a simple act of theft, subject to discretionary punishment - in this case, beating and imprisonment. ${ }^{62}$

Radhika Singha has demonstrated how, in the context of widespread social turbulence, Islamic law officers employed in the Company's courts were required to extract a monolithic law of homicide and punishment, eliminating the many conflicting opinions and conditions which hindered the application of the death penalty for murder. This process, of which Ali Ibrahim Khan was a part, offers us tantalising glimpses into a working Islamic legal system, with recognisable procedures of selection of appropriate principles from a variety of texts, and the often contradictory opinions of past masters, by juriconsults (muftis) for the benefit of a judge (qazi) dealing with a specific case. ${ }^{63}$ Placed within that broader jurisprudential and legal context, we can understand the objections expressed by a number of judges, including Ali Ibrahim Khan himself, to British extensions and interpolations to the Islamic laws pertaining to homicide. In 1791, for example, when refusing to accede to a sentence of transportation of a certain Bhisoo, Ali Ibrahim Khan said that where the

slain party hath no relations, either near or remote-in respect to whatever hath conformably to law attached, either of Kisas [retaliation] 
or Deeit [compensation], on the slayer in lieu of the slain, the Hakim [judge] is empowered, in such manner that the Hakim is authorized in regard to the completion of the Kisas or Deeit, whatever shall have justly attached on the slayer... but to send him in such a cause as the present to Pulo Penang will not fall in with the Shira or law [sic], because such a Rowayet, or legal opinion, hath not been found in the books. $^{64}$

In the case transferred from Nasir ud-din's court, on the other hand, Ali Ibrahim Khan discovered sufficient reasons within Islamic law to modify a sentence comprising a hadd punishment. Considered on its own, one may have been tempted to see his decision as a product of his willingness to accommodate British sensibilities about the barbarity of mutilation, possibly even his sharing them. However, Ali Ibrahim Khan's reference to the location of crime resonates with the conditions recited in the Fatawa-i 'Alamgiri regarding what comprised quta' al-tariq or rahzani (highway robbery) - that the crime had to be committed far from cities and villages (there being some unclearness whether the required distance was one full day's travelling distance or three) - this opinion said to be in line with the zahir alriwayah - or the consensus among scholars (of a particular school). ${ }^{65}$ The eminent Hanafi jurist Abu Yusuf had apparently mentioned the possibility of the distance qualifications being overridden when the crime was committed at night. ${ }^{66}$

In coming to their respective conclusions, then, Nasir ud-din and Ali Ibrahim Khan chose to rely on different opinions from within the Hanafi mazhab (school of law), as it was perfectly legitimate for them to do according to Islamic jurisprudential methods. In fact, Ali Ibrahim Khan seems to have veered towards the majority opinion, whereas Nasir ud-din had chosen a relatively isolated opinion as more appropriate for the case at hand. What would however be unique about the situation is a man such as Ali Ibrahim Khan, who was not expressly trained as a an expert in law (fiqh), and who in fact, never applied the term "qazi" or Islamic judge to himself, always choosing the more generic "hakim" instead, should have in this instance appropriated the role of a juriconsult (mufti). There is a lively and ongoing debate among scholars of Islamic law regarding to principal locus of legal interpretation in 
Islamic law-and whether this is the qazi or the mufti. ${ }^{67}$ Whatever the outcome of that debate, it is perhaps not unreasonable to speculate that the novelty of the colonial situation allowed an administrator such as Ali Ibrahim Khan to combine in himself both roles, in a performance that approximated to the model of a just king rather than merely a conscientious judge.

\section{Of Kings and History: Ali Ibrahim Khan in Bengal, Awadh and Banaras}

It is time, then, to return to Ali Ibrahim Khan's strongly felt notion that it was kings that gave laws to a realm. How then, did he view Banaras - an ancient Hindu centre of learning and pilgrimage, and much later, a centre of Hindu revivalism under the patronage of the reinvented rajas of Banaras? In his comments on Hindu ordeals, Ali Ibrahim Khan clearly stated that such procedures may be applicable to the territories of Hindu kings, but not in Banaras, which was under the Company's rule. There was more at work here than a pragmatic recognition of local political realities - for as we have seen, Ali Ibrahim Khan was perfectly capable of refusing to agree with British legal innovations that he saw as alien, and (as in the matter of mortgages) that his defence of existing procedures was not limited to Islamic law alone.

Fortunately for us, Ali Ibrahim Khan expressed his evaluation of the Banaras rajas and their claims to sovereignty in a short historical work called Tarikh-i Chait Singh, in which he provided an eyewitness account of the Company's conflict with and victory over Chait Singh. Recent research has made us aware that scholaradministrators of Khan's generation had strongly held notions of what constituted good government and what made a good king, and that they expressed their views through didactic uses of history, such that the rise and fall of princes and empires was related to their success or otherwise in conforming to the values of the historians, and above all, in identifying and deferring to appropriate and reliable advisors. ${ }^{68}$

In his version of events at Banaras, ${ }^{69}$ Ali Ibrahim Khan agreed in outline with the self-justifying narrative presented by Hastings to his Council later that year, ${ }^{70}$ with the distinct aim of establishing himself as a "well-wisher of the Company" (khair khwah-i kampani). Establishing the credit score of "good servants," was however, at the same time, a comment on the legitimacy of kings, since loyalty was only owed to those that deserved it. Abjuring any effort to provide background to Chait Singh's 
efforts at resistance (which might well be construed as justifying them), Khan described himself as a detached spectator, travelling with Hastings from Murshidabad to Benares, purely with a view to "travel and seeing cities" (sair wa didan-i bilad), and being met by a clearly ill-intentioned raja-who came up the river to Buxar, with boatloads of armed soldiers. Matters quickly escalated with the raja, who had revealed a "rebellious" (inhiraf) spirit, being placed under house arrest to cure him of bad ideas. Unfortunately, the Raja refused to submit to such chastisement, and instead escaped from confinement, while sending his soldiers rampaging across the city, threatening all supporters of the Company and encouraging subordinate "landholders" (zamindars) to go on "rebellion" (baghawat) against the Company. The untold suffering of the great and good (including Ali Ibrahim Khan himself) ended as the raja who was disloyal (idbar), had harboured "vicious intentions" (iradat-e faside) and had undertaken "dishonourable activities" ('amal nashayaste), was "eliminated" (istisal), naturally due to the "glory of the Company" (az iqbal-e kampani), restoring peace and safety to the grateful inhabitants of Banaras.

Although the legitimacy of this money-raising raid would eventually return to haunt Warren Hastings, ${ }^{71}$ Ali Ibrahim Khan, like other late Mughal administrators of his generation, ${ }^{72}$ saw little legitimacy in the claims of upstart zamindars such as Chait Singh. The remained to him no more than troublesome rebels; the Mughals' bugbear-refractory landholders or zamindar-i zortalab. ${ }^{73}$ However, this was much less about religious identity than about Mughal legitimacy - thus Ali Ibrahim Khan was perfectly able to recognise the claims of non-Persianised soldier-kings such as the Marathas, ${ }^{74}$ despite their decidedly coarse ways, and even endow them with a Sassanid genealogy, on the basis that they had reformed their ways, and joined the service of the Mughals. Those were indeed Hindu kings (and queens), to whom Ali Ibrahim Khan protested his loyalty and eagerness to be of assistance, and in whose realms Hindu ordeals might be legitimately carried out in court. If this was the voice of the servant, it was a servant who knew that there were several masters to serve, but that not all who threw their weight around deserved to be kings, or to determine legal orders.

\section{Conclusion: Law in its place?}


In his accounts of the rise and demise of kings, equitable legal interpretation and rational adjudicative procedures, Ali Ibrahim Khan repeatedly referred to two things - the nature of good rulers, and the importance of locale for determining good rule, and rules. Thematically, therefore, he thought along similar lines as those European thinkers and actors who considered how distant empires may be governed — and found answers either in distinct ancient constitutions (actual or imagined) or in the alleged geographical and, increasingly, biological conditioning of potential subjects in those places. While Khan may not have ventured quite as far from home-physically or intellectually - he too was dealing with a realm whose nature and, hence, implications were undecided, but whose diversity was unquestionable. Banaras, an important centre of Hindu pilgrimage, was clearly no longer part of the recognisably Mughal structure of Awadh; it had shed an upstart raja whose descendants would discover their Hindu credentials several generations later, and was constantly eyed by the Marathas, self-consciously seeking Brahminical legitimacy. Inside, Muslim jurists and judges struggled to understand British legal requirements, Brahmin pandits found new avenues for asserting their expert authority by citing empirically irrational scriptural provisions and jealous British superiors attempted to inscribe their authority by hastily imposing new procedural rules.

In that fractured context, Ali Ibrahim Khan devised a methodology for reconciling conflicting legal principles and claims, and did so not by sole recourse to a notion of the unassailable unity of Islamic law, nor in a theory of several ancient laws, separable by religious affiliation, nor, again, in complete willingness to accept the wishes of those in power. Instead, he worked with well-known principles of Islamic jurisprudence and with an administrative rationality common within his professional class. The first offered him a flexible methodology of choosing from a number of alternative legal opinions according to the specificities of a case; the second allowed him to discover a supra-religious "naturalist" principle for judging the value of unfamiliar (not merely un-Islamic) scriptural-legal provisions. Empiricist realism also led him to pose a "social-realist" challenge to the ideas of his British superiors. Finally, royal transcendence, possessed by the British — and by extensionhimself, and possibly the Marathas, offered a further key principle for deciding (or at least) arguing which laws were suitable for which people and kingdoms. 
If these were all centralising, organising principles, the capacious and accommodative principle at work in Ali Ibrahim Khan's thought was the importance and legitimacy of custom. In accommodating diversity, it was local custom he looked to, not scriptural texts. Custom was legitimate, because it was familiar (hence shared), and also because it was attuned to local circumstances and social realities, crucial to ensuring justice, but unrecognised in an abstract notion of law. Custom, in this case, appeared not to be a deviation from Islamic legal provisions, but accommodated within its formal jurisprudential parameters.

It may not be possible nor productive to push further, to discover which of these principles, in the final instance, was considered most crucial by Ali Ibrahim Khan himself. But it may be worth noting that it was to locality that he turned when formally assessing the value of his own work. In an huge collectively signed document (mahzarnama) acknowledging the excellence of his work, garnered alongside letters of support for his erstwhile patron Warren Hastings, Ali Ibrahim Khan summarised his achievements by referring to his own probity and uprightness, a Solomon-like accessibility to petitioners, kingly attention to his subjects' religious needs and charity during periods of social distress, "colonial" attention to maintaining separate court procedures for Hindus and Muslims, and resort to "customary" sources for identifying those procedures. Clearly, this worked with the great and good of Banaras who were asked to endorse these claims. In many languages, scripts and idioms, the hundreds of Banarasis who signed this gigantic mahzarnama blessed the East India Company and "Mr. Hastings" for appointing "such a judge" (hamchunin hakim) for their city. ${ }^{75}$

Note on transliteration: I have transliterated Arabic, Persian, Hindi/Urdu and Sanskrit words phonetically (following South Asian pronunciation patterns), without diacritics, only using an apostrophe to represent the character 'ain, and $\tilde{n}$ for the nasal stop.

For correspondence: n.chatterjee@exeter.ac.uk. I would like to thank Mitch Fraas, Rajarshi Ghose, Justin Jones, Lakshmi Subramanian and the anonymous reviewers of the Journal of Colonialism and Colonial History for their detailed comments and suggestions, which have helped me immensely in improving the research and arguments presented in this article. All errors and shortcomings are naturally my own. 


\section{Notes}

${ }^{1}$ Ali Ibrahim Khan, "On the Trial by Ordeal among the Hindus," Asiatick Researches 1 (1788): 389-404.

${ }^{2}$ Bernard Cohn, Colonialism and its Forms of Knowledge: The British in India (Princeton: Princeton University Press, 1996), 57-75; for an elaboration of the point, Jon Wilson, The Domination of Strangers: Modern governance in eastern India, 1780-1835 (Basingstoke: Palgrave, 2008).

${ }^{3}$ Michael Dodson, Orientalism, Empire, and National Culture: India, 1770-1880 (Basingstoke: Palgrave, 2007), 41-60.

${ }^{4}$ Ali Ibrahim Khan, “On the Trial by Ordeal,” 398.

${ }^{5}$ M.B. Hooker, Legal Pluralism: An introduction to colonial and neo-colonial laws (Oxford: Clarendon Press, 1975).

${ }^{6}$ Sally Engle Merry, “Legal Pluralism,” Law and Society Review 22/5 (1988): 869-96.

${ }^{7}$ Lauren Benton, "Colonial Law and Cultural Difference: Jurisdictional politics and the formation of the colonial state," Comparative Studies in Society and History 41/3 (1998): 563-88, a point elaborated in Benton, A Search for Sovereignty: Law and geography in European empires, 1400-1900 (Cambridge: Cambridge University Press, 2010).

${ }^{8}$ Among others, Jennifer Pitts, A Turn to Empire: The rise of imperial liberalism in Britain and France (Princeton: Princeton University Press, 2005); Karuna Mantena, Alibis of Empire: Henry Maine and the ends of liberal imperialism (Princeton: Princeton University Press, 2010).

${ }^{9}$ Lauren Benton, "Introduction: Forum on law and empire in global perspective," The American Historical Review 117/4 (2012): 1092-1100.

${ }^{10}$ Aparna Balachandran, "Of Corporations and Caste Heads: Urban rule in Company Madras, 1640-1720," and Bhavani Raman, “The Familial World of the Company's Kacceri in Early Colonial Madras," both in Journal of Colonialism and Colonial History 9/2 (2008).

${ }^{11}$ Natalie Zemon Davis, Trickster Travels: A sixteenth-century Muslim between worlds (New York: Hill and Wang, 2006); Sanjay Subrahmanyam, Three Ways of 
Being Alien: Travails and encounters in the early modern world (Waltham, Mass.: Brandeis University Press, 2011), 1-22.

12 And thus both develop and critique Christopher Bayly's argument that such late Mughal administrators attempted to educate the British in the Mughal norms of governance. Christopher A. Bayly, Empire and Information: Intelligence gathering and social communication in India, 1780-1870 (Cambridge: Cambridge University Press, 1999), 81.

${ }^{13}$ Radhika Singha, A Despotism of Law: Crime and justice in early colonial India (Oxford: Oxford University Press, 1998).

${ }^{14}$ Robert Travers, Ideology and Empire in Eighteenth-Century India: The British in Bengal (Cambridge: Cambridge University Press, 2007).

${ }^{15}$ Wael Hallaq, "Was the Gate of Ijithād Closed?," International Journal of Middle East Studies 16 (1984): 3-41; Wael Hallaq, Authority, Continuity and Change in Islamic Law (Cambridge: Cambridge University Press, 2001).

${ }^{16}$ Barbara Daly Metcalf, Islamic Revival in British India: Deoband, 1860-1900 (Princeton: Princeton University Press, 1982); Muhammad Qasim Zaman, The Ulama in Contemporary Islam: Custodians of change (Princeton: Princeton University Press, 2002).

${ }^{17}$ For some outstanding examples, see Barbara Metcalf ed. Islam in South Asia in Practice (Princeton: Princeton University Press, 2009); Richard M. Eaton, ed., India's Islamic Traditions, 711-1750 (New Delhi: Oxford University Press, 2003).

${ }^{18}$ Barbara Metcalf, Moral Conduct and Authority: The Place of Adab in South Asian Islam (Berkeley: University of California Press, 1984).

${ }^{19}$ Katherine Ewing, ed., Sharī'at and Ambiguity in South Asian Islam (Berkeley: University of California Press, 1988).

${ }^{20}$ Scott Alan Kugle, "Framed, Blamed and Renamed: The recasting of Islamic jurisprudence in colonial South Asia," Modern Asian Studies 35/2 (2001): 257-313; Wael Hallaq, Shari 'a, 371-83.

${ }^{21}$ Muzaffar Alam, The Languages of Political Islam: India, 1200-1800 (London: Hurst \& Co., 2003); Mouez Khalafoui, “Together but Separated: How Muslim scholars conceived religious plurality in South Asia in the 17th century," Bulletin of the School of Oriental and African Studies 74 (2011): 87-96. 
${ }^{22}$ For biographies, see Imtiaz Mohamad Khan, “Ali Ibrahim Khan,” The Calcutta Review [vol. not known] (1931): 67-81; Shayesta Khan, A Biography of Ali Ibrahim Khan (circa 1740-1793): A Mughal noble in the administrative service of the British East India Company (Patna: Khuda Baksh Oriental Library, 1992); Naqi Ahmad Irshad, Kārvān-i raftah: 'Ażīmābād ke qadīm knhāandānon kā tazkkirah (The story of the old families of Azimabad) (Patna: Khuda Baksh Oriental Public Library, 1990), 14869.

${ }^{23}$ Naqi Ahmad Irshad, Kārvān-i raftah, 148; Ghulam Hussain Khan Tabatabai, The Seir Mutaqherin, trans. Nota Manus, 3 vols. (Calcutta: R. Cambray, 1902-1903), II, 166-68.

${ }^{24}$ On his poetry and poetic sensibility, see Mana Kia, "Contours of Persianate Community, 1722-1835" (Ph.D. diss., Harvard University, 2011).

${ }^{25}$ Shayesta Khan, A Biography of Ali Ibrahim Khan, 34.

${ }^{26}$ As demonstrated by his 173 letters, preserved at Khuda Baksh library, and translated by Shayesta Khan. Shayesta Khan, The Holy City of Benares as Administered by a Muslim Noble: Social, religious, cultural and political conditions, 1781-1793 (Patna: Khuda Baksh Oriental Public Library, 1998).

${ }^{27}$ As reported by his father-in-law, the historian Yusuf Ali Khan, in Tarikh-i Bangala-i Mahabat Jangi, ed. Abdus Subhan (Calcutta: The Asiatic Society, 1969), II, 113.

${ }^{28}$ John R. MacLane, Land and Local Kingship in Eighteenth Century Bengal (Cambridge: Cambridge University Press, 1993), 161-2.

${ }^{29}$ For a discussion of these broader events, see P.J. Marshall, Bengal: The British bridgehead (Cambridge: Cambridge University Press, 1987), 70-92.

${ }^{30}$ Tabatabai, The Seir Mutaqherin, III, 68-72.

${ }^{31}$ Tabatabai, The Seir Mutaqherin, III, 82-86.

${ }^{32}$ Bernard Cohn, "Political Systems of Eighteenth-Century India: The Banaras region," Journal of American Oriental Society 82/3 (1962): 312-20; Suprakash Sanyal, Benares and the English East India Company, 1764-1795 (Calcutta: World Press Limited, 1979).

${ }^{33}$ Suprakash Sanyal, Benares, 2-16, 27, 33; The King's Firmaun granting the Zemindary of Balwund Sing to the English Company... Dated 28 December 1764 [translation], Verelst Papers, F218/29, IOR, British Library; Treaty of Allahabad, 
1765, fifth clause, Richard Barnett, North India between Empires: Awadh, the Mughals and the British, 1720-1801 (Berkeley: University of California Press, 1980), 144-45; "Translation of Sunnud granted to Rajah Cheyt Singh, for the Zemindary of Gazeepore, Benares, etc., 15 April 1776," in A Collection of Treaties, Engagements and Sanads, Relating to India and Neighbouring Countries, ed. CuU. Aitchison (Calcutta: Superintendent of Government Printing, 1909), II, 73-74.

34 "Sanad granted to Rajah Mahip Narain Bahadur for the Zamindari of Benars, Ghazipur, Chunar, etc., 1781," in A Collection of Treaties, ed. Aitchison, II, 82-84.

${ }^{35}$ Warren Hastings, A Narrative of the Insurrection which Happened in the Zemeedary of Banaris in the Month of August 1781 (Calcutta: Government Press, 1782, reprinted 1853), Appendix, 22-27.

${ }^{36}$ Ali Ibrahim Khan, "On the Trial by Ordeal."

${ }^{37}$ Ali Ibrahim Khan, "On the Trial by Ordeal," 395-96.

${ }^{38}$ Letter of Muhammad Reza Khan, 4 May 1772, Proceedings of the Controlling Committee of Revenue at Murshidabad, IOR G/27/7, also discussed in Travers, Empire and Ideology, 171, who opines that Reza Khan's protest represented a "rearguard action" to guard autonomy, rather than the reality of Islamic law having been in operation in Mughal India. I do not entirely agree with this conclusion.

${ }^{39}$ Calendar of Persian Correspondence (Delhi: National Archives of India, 1959), X, $83-85$

${ }^{40}$ Carl Ernst, "Sufism and Yoga according to Muhammad Ghawth," Sufi 29 (Spring 1996): 9-13; Ernst, "Muslim Studies of Hinduism? A reconsideration of Arabic and Persian translations from Indian languages,' Iranian Studies 36/2 (2010): 173-95.

${ }^{41}$ M. Athar Ali, "Translations of Sanskrit Works at Akbar's Court," Social Scientist 20 (1992): 38-45; Audrey Truschke, “The Mughal Book of War: A Persian translation of the Sanskrit Mahabharata," Comparative Studies of South Asia, Africa and the Middle East 31/2 (2011); Roderic Vassie, "Persian Interpretations of the Bhagavadgìtā in the Mughal Period: With special reference to the Sufi version of ‘Abd Al-Rahmān Chishtī'," (Ph.D. thesis, School of Oriental and African Studies [SOAS] London, 1988).

42 J. D. M. Derrett, "The Administration of Hindu Law by the British," Comparative Studies in Society and History 4/1 (1961): 10-52; Dodson, Orientalism, 18-40. 
${ }^{43}$ Juan Cole, "Shi'i Clerics in Iraq and Iran, 1722-1780: The Akhbari-Usuli conflict reconsidered," Iranian Studies 18/1 (1985): 3-34.

${ }^{44}$ Juan Cole, Roots of North Indian Sh'̀ ism in Iran and Iraq: Religion and state in Awadh, 1722-1859 (Berkeley: University of California Press, 1988)

${ }^{45}$ Cole, Roots of North Indian Shì'ism, 208-10.

${ }^{46}$ Kia, "Contours of a Persianate Community," 224.

${ }^{47}$ Charles Fawcett, The First Century of British Justice in India (Oxford: Clarendon, 1934), 222

${ }^{48}$ Rudolph Peters, "Murder on the Nile: Homicide trials in $19^{\text {th }}$ Century Egyptian shari ‘a courts,” Die Welt Des Islams, New Series, 30 1/4 (1990): 98-116.

${ }^{49}$ Radhika Singha, A Despotism of Law, 46-49.

${ }^{50}$ Joseph Fowke to his son Francis Fowke, then Resident in Banaras, 8 February 178[?], British Library, Mss EUR6. Joseph Fowke had been tried in [1775?], together with the unfortunate Nanda Kumar, for his attempt to vilify Warren Hastings. The Trial of Joseph Fowke, Francis Fowke, Maha Rajah Nundocomar and Roy Rada Churn for a Conspiracy against Warren Hastings (London: T. Cadell, 1776).

${ }^{51}$ Bengal Revenue Consultations 3 October 1788, IOR/P/5/25, pp. 161-792, key extracts reproduced in A. Shakespear, Selections from Duncan Records (Benares: Medical Hall Press, 1873), I, 41-44

${ }^{52}$ Shakespear, Selections, I, 42

${ }^{53}$ V.A. Narain, Jonathan Duncan and Varanasi (Calcutta: Mukhopadhyay, 1959), 147-49; the document of appointment of Maulvi Amir Ullah, dated 27 January 1788, reproduced in G.N. Saletore, Banaras Affairs, vol. I (Allahabad: Government Central Record Office, n.d. [1955]), 63-64

${ }^{54}$ Wajib ul-arz of Molavy Omer Ulla with the Resident's answers to each, Saletore, Banaras Affairs, 67-68, 77-80, 85-89, 110.

${ }^{55}$ Wajib ul-arz of Molavy Omer Ulla, Saletore, Banaras Affairs, 110.

${ }^{56}$ Wajib ul-arz of Molavy Omer Ulla, Saletore, Banaras Affairs, 100-4.

${ }^{57}$ From the Magistrate to the Resident, Saletore, Banaras Affairs, 111-14.

${ }^{58}$ One such is reproduced in Ibn Hasan, The Central Structure of the Mughal Empire (London: Oxford University Press, 1936), 362-63. There are several others in the National Archives of India. 
${ }^{59}$ The compilers of the massive late seventeenth-century legal work, the Fatawa-i 'Alamgiri, sponsored by the emperor Aurangzeb, had noted under bai 'al-wafa that property pledged against loans could be neither used nor transferred, for otherwise it would be a loophole permitting usury. They noted disapprovingly that other schools believed differently. The Moohummudan Law of Sale according to the Huneefeea Code from the Futawa Alumgeeree, trans. Neil Baillie (London: Smith Elder and Co., 1850), 300-303. For a very useful introduction to the text, see Alan Guenther, "Hanafi Fiqh in Mughal India: The Fatāwá-i 'Ālāmgiri," in India's Islamic Traditions, 711-1750, ed. Richard Eaton (New Delhi: Oxford University Press, 2003), 209-30.

${ }^{60}$ As studied in Jörg Fisch, Cheap Lives and Dear Limbs: The British transformation of the Bengal criminal law 1769-1817 (Wiesbaden: Franz Steiner Verlag, 1983).

${ }^{61}$ As is the punishment for highway robbery described in the Hedaya, trans. Charles Hamilton, II, 138

${ }^{62}$ Bengal Revenue Consultations, 11 January 1789, pp. 167-72, P/51/32, IOR, British Library.

${ }^{63}$ For a very clear overview of this process, see Wael Hallaq, Authority, Continuity and Change, especially chap. 6, 166-235; Judith Tucker, In the House of Law: Gender and Islamic law in Ottoman Syria and Palestine (Berkeley: University of California Press, 1998), 11-22.

${ }^{64}$ Bengal Revenue Judicial Consultations, 10 February 1792, pp. 152-53, P/127/77, IOR, British Library.

65 "Zahir al-Riwayah," in The Oxford Dictionary of Islam, ed. John L. Esposito. Oxford Islamic Studies Online, http://www.oxfordislamicstudies.com/article/opr/t125/e2552, accessed 12 Feb. 2014. ${ }^{66}$ Fatawa-i 'Alamgiri, trans. to Urdu by Saiyid Amir Ali, amended by Maulana Abu Abdullah, 10 vols. (Lahore: Maktaba Rahmaniyya, n.d.), III, 318.

${ }^{67}$ Lawrence Rosen, Review article, Middle East Journal, 60/4 (2006): 819-822

${ }^{68}$ Kumkum Chatterjee, "History as Self-Representation: The recasting of a political tradition in late eighteenth-century eastern India," Modern Asian Studies 32/4 (1998): 913-48.

${ }^{69}$ Tarikh-i Chait Singh, Or 1865, British Library, ff. 36-40.

${ }^{70}$ Hastings, A Narrative of the Insurrection. 
${ }^{71}$ This being the first of the six major Articles of Impeachment accepted by the House of Commons in his impeachment trial in 1786.

72 Travers, Ideology and Empire, 225-29

${ }^{73}$ Such as the faujdars were supposed to deal with, first with kind words, and then, with force. Ain-i Akbari, ed. and trans. by Blochmann and Jarrett (Calcutta: Baptist Mission Press, 1891), II, 41.

${ }^{74}$ Ali Ibrahim Khan, Tarikh-i Marhatta, ff. 1-2, IO Islamic 3390, British Library. These folios were not translated by Elliot and Dawson, The History of India: As told by its own historians (London: Trubner \& Co., 1877), VIII, 257-97.

75 "Certificate of the Inhabitants of Benares in Support of 'Ali Ibrahim Khan'," Add. 29,217 (a), British Library. 